\title{
I.B. POMAHCЬKA
}

Ірина Володимирівна Романська, аспірантка Львівського державного університету внутрішніх справ*

ORCID: 0000-0001-6567-9999

\section{ДО ПИТАННЯ ПРО СПІВВІДНОШЕННЯ КОНДИКЦІї ТА ВІНДИКАЦІї}

Постановка проблеми. Однією 3 головних невирішених правових проблем сучасного суспільства $€$ проблема належного захисту порушених суб'єктивних цивільних прав. На законодавчому рівні закріплено низку механізмів, що дозволяють відновлювати порушене майнове становище учасників цивільного обороту та забезпечувати баланс їхніх інтересів. Особливу роль у гарантуванні стабільності охоронних відносин відведено нормам про кондикцію.

У теорії і практиці цивільного права найбільш складною проблемою, яка пов'язана 3 цим правовим інститутом, залишається питання його співвідношення з іншими вимогами про повернення майна власнику (титульному володільцю). Іноді умови виникнення цих вимог можуть збігатися з умовами виникнення зобов'язань з набуття, збереження майна без достатньої правової підстави, у результаті чого можливе перетинання сфери їх дії. Така ситуація має місце при застосуванні кондикції та віндикації.

Аналіз останніх досліджень і публікацій. Окремі питання співвідношення кондикції і віндикації досліджували у своїх наукових доробках І.М. Гончаров, Є.А. Ваштарева, Я.М. Романюк, В.С. Толстой, К.А. Флейшиц, А.А. Шамшов. Проте доводиться констатувати, що ця проблема так і не отримала остаточного вирішення, а тому потребує подальших наукових розвідок.

Мета статті полягає у проведенні розмежування кондикції та віндикації як способів захисту права власності шляхом розкриття спільних та відмінних ознак цих правових інститутів.

Виклад основного матеріалу. Зміст та сфера застосування зобов'язань 3 набуття, збереження майна без достатньої правової підстави (також іменуються як кондикційні зобов'язання) регламентовані у главі 83 ЦК України. Суть цього зобов'язання полягає у тому, що набувач безпідставно збагатився за рахунок потерпілого, а тому зобов'язаний не лише повернути йому майно в натурі чи відшкодувати його вартість, а й у повному обсязі компенсувати потерпілому негативні наслідки шляхом відшкодування всіх доходів, які набувач одержав або міг одержати від цього майна1.

Інститут кондикції містить повний набір правових відновлювальних інструментів, достатніх для захисту майнових інтересів потерпілого, коли крім безпосередньо кондикційної вимоги потерпіла сторона має право приєднати до неї й інші вимоги охоронного характеру.

За способом захисту інтересів потерпілого кондикційне зобов'язання подібне до віндикації.

Традиційно у цивілістиці під віндикацією розуміється позадоговірна вимога власника (іншого титульного володільця) про повернення майна з чужого незаконного володіння. Верховний Суд у своїй постанові зазначив, що умовами звернення з віндикаційним позовом $\epsilon$ те, що: позивач $є$ власником майна, який фактично втратив володіння річчю; відповідач є незаконним володільцем; власник і володілець не перебувають у договірних відносинах; предметом позову може бути тільки індивідуально визначена річ, яка на момент розгляду спору повинна існувати в натурі ${ }^{2}$.

Проблема співвідношення кондикції і віндикації, включаючи видову різноманітність, межі їх експансії, визначення спільних та відмінних ознак, можливість переходу від одного позову до іншого, неоднозначно трактується серед цивілістів. У теорії цивільного права й досі залишається дискусійним питання про конкуренцію цих способів захисту права власності, що зумовлює необхідність дослідження правової природи таких інститутів та проведення їх розмежування.

Передусім зосередимо увагу на спільних ознаках кондикції та віндикації.

Віндикаційний та кондикційний позови є дієвими способами захисту права власності, а не мірами відповідальності, правова природа яких різниться. Обов'язок особи, яка безпідставно збагатилася, повернути потерпілому набуте чи збережене майно не належить до мір відповідальності, оскільки за цих обставин боржник не несе жодних майнових втрат.

Крім того, розглядувані інститути носять відновлювальний характер, так як покликані захистити і відновити порушене чи оспорюване суб'єктивне право. Кондикційне зобов'язання створює для набувача обов'язок повернути потерпілому все безпідставно набуте або збережене майно. Віндикація теж реалізується в рамках правовідносин відновного характеру. Принагідно слід зазначити, що як при віндикації, так і при набутті (збереженні) майна без достатньої правової підстави майно підлягає поверненню потерпілому у натурі. Для віндикації це імперативна законодавча вимога, а для кондикції допускається відступ від цього правила: якщо майно не може бути повернуто в натурі - набувач відшкодовує його вартість.

(C) I.В. Романська, 2020

* Iryna Romanska, Postgraduate student of Lviv State University of Internal Affairs 
Зобов’язання з набуття, збереження майна без достатньої правової підстави, як і відносини з витребування майна $з$ чужого незаконного володіння, за своєю правовою природою належать до числа охоронних і позадоговірних правовідносин.

Вимоги 3 кондикції або віндикації виникають з відносин, не заснованих на договорі. Відносини, в рамках яких реалізуються розглянуті способи захисту суб'єктивних прав, є охоронними‥ Умовою застосування віндикації $\epsilon$ відсутність договірних зв'язків між сторонами спору (титульним володільцем (власником) та добросовісним або недобросовісним набувачем), а саме майно переходить до фактичного володільця на певній правовій підставі, яка оспорюється власником, проте за жодних обставин такою підставою не може бути укладений з власником договір.

Кондикція також є позадоговірним способом захисту права власності. Як убачається з матеріалів судової практики, у разі виникнення спору стосовно набуття майна або його збереження без достатніх правових підстав договірний характер правовідносин виключає можливість застосування до них судом положень частини першої ст. 1212 ЦК України, у тому числі й щодо зобов’язання повернути майно потерпілому4.

Як віндикаційний позов, так і позов з безпідставного набуття, збереження майна може бути пред'явлений до особи, що опинилася у статусі відповідача в результаті як добросовісної, так і недобросовісної поведінки.

Схожість вбачається й за так званою ознакою «слідування». Віндикація застосовна лише до володільця речі і поки він володіє нею. Втрата володільцем речі позбавляє власника можливості пред’явлення до такої особи віндикаційного позову. За цих обставин право вимоги виникає стосовно нового володільця. Так може відбуватися неодноразово. У цьому знаходить свій прояв абсолютний характер вимоги: вона не прив'язана до певної особі, а слідує за річчю. За кондикцією зобов’язання «слідує» за безпідставним збагаченням подібно до того, як віндикація слідує за річчю. Інакше кажучи, таке зобов'язання виникає на стороні набувача, який безпідставно набув або зберіг майно потерпілого, незалежно від їхніх попередніх взаємовідносин, зважаючи лише на факт збагачення.

Отже, досліджувані інститути наділені спільними ознаками, що, у свою чергу, породжує проблему визначення критеріїв, які можуть бути покладені в основу розмежування кондикційного зобов'язання та віндикації, оскільки правове регулювання цих суспільних відносин здійснюються за різних юридико-фактичних умов.

Визначення відмінностей між ними допомагає виокремити зобов'язання з набуття, збереження майна без достатньої правової підстави у самостійний вид зобов'язань, а також визначити умови, за яких норми про кондикцію можуть субсидіарно застосовуватися до відносин віндикації.

Зосередимо увагу на ключових критеріях розмежування кондикції і віндикації.

На переконання більшості науковців, головна відмінність між кондикцією та віндикацією полягає у тому, що вимога про повернення безпідставного збагачення є речово-правовим способом захисту, а позов про витребування майна з чужого незаконного володіння - зобов'язально-правовим 5 .

Речовий характер віндикаційного позову зумовлений прив'язкою до існування речі, а також факту іiі перебування у володінні набувача (відповідача). Для кондикційного позову юридичного значення немає, чи існує річ в натурі, оскільки він опосередковує задоволення вимоги про повернення як конкретної речі, так $\mathrm{i}$ відшкодування ії вартості.

3 наведеного випливає, що якщо віндикаційний позов захищає речові права як такі, то кондикційний речові права, проте не прямо, а через механізм захисту суб'єктивних цивільних прав за зобов'язальним правовідношенням.

Ще одна відмінність полягає в тому, що кондикційний позов має відносний характер. Тобто власник може пред'явити кондикційну вимогу тільки тому, хто безпосередньо отримав від нього річ. Натомість віндикаційний позов може бути пред'явлений будь-кому, у кого власник виявить своє майно, тобто така вимога має абсолютний характер.

Доцільно провести розмежування між досліджуваними інститутами за суб'єктним складом. Суб'єктами віндикації з однієї сторони виступає власник (інший титульний володілець) речі, який втратив володіння нею, а з другої - незаконний володілець (добросовісний або недобросовісний набувач). Власник майна, який не володіє ним, не втрачає права власності на нього і не перестає бути власником. Для задоволення віндикаційного позову необхідно, щоб річ, яка витребовується, була придбана саме тією особою, у якої вона витребовується, тобто позов може бути пред'явлений не володіючим власником до володіючого невласника 6 .

Суб'єктами зобов'язань, що виникають у результаті набуття, збереження майна без достатньої правової підстави, як наголошується в літературі, виступають: боржник - особа, яка набула майно або зберегла його у себе за рахунок іншої особи (потерпілого); кредитор (потерпілий) - особа, за чий рахунок інша особа (боржник) набула майно або зберегла його у себе 7 . Боржником за цим зобов'язанням є особа, яка без встановлених нормативними приписами підстав набула або зберегла майно у себе за рахунок іншої особи (потерпілого). Незалежно від характеру набутого майна, набувач не може вважатися його власником, оскільки для цього відсутня законна підстава. Стосовно ж збереженого майна, то набувач залишається його власником, проте на нього покладається обов'язок передати потерпілому майно в розмірі збагачення. На відміну від віндикації, той факт, що незаконний набувач фактично володіє річчю, у випадку кондикції не має визначального значення.

Тобто кондикційний позов може бути пред'явлений особою, яка втратила право власності, до власника безпідставно набутого чи збереженого, а також власником втраченого майна до незаконного володільця майна. Крім власника і титульного володільця, до суб'єктного складу кондикційного зобов'язання входить також особа, яка має право на набуття права власності або законне володіння, але не набула його внаслідок діянь боржника. 
Отже, коло осіб, які мають право на пред’явлення кондикційного позову, ширше порівняно з суб'єктами, що мають право на віндикацію. Крім того, при задоволенні кондикційного позову відповідача позбавляють прав на належне йому майно, а при віндикації в нього вилучається індивідуально визначена річ, яка не входить до складу його майна.

Найбільшу полеміку серед цивілістів викликає питання про розмежування досліджуваних інститутів за таким критерієм, як предмет вимоги, зокрема, характеристика майна, яке підлягає поверненню. Не викликає сумнівів, що предметом віндикаційного позову може бути тільки індивідуально визначена річ, що збережена в натурі. При цьому задоволення вимоги відбувається шляхом повернення власнику того ж самого майна, яке вибуло з його володіння. Стосовно ж кондикційного позову, то в доктрині цивільного права панівною є позиція, згідно з якою вимога, яка випливає з безпідставного збагачення, спрямована на повернення лише речі, яка визначена родовими ознаками, тобто того ж роду і якості, або їі вартості ${ }^{8}$. На наше переконання, ця позиція не $\epsilon$ безспірною.

ЦК України не містити обмежень, які стосуються об'єкта кондикції. 3 буквального тлумачення норм глави 83 ЦК України неможливо встановити, яке безпідставно набуте майно підлягає поверненню в натурі: те ж саме, яке й було отримано (що передбачає його індивідуалізацію) або аналогічне йому (родові речі). На наше переконання, використаний у легальному визначенні зобов'язання у зв'язку з набуттям, збереженням майна без достатньої правової підстави термін «майно» слід трактувати в широкому сенсі, а тому за допомогою кондикційного позову може бути витребувана й індивідуально визначена річ.

На підтвердження цього судження наведемо приклад: після розірвання договору купівлі-продажу картини, особа, яка передала річ, має право вимагати ії повернення, якщо вона не оплачена до моменту припинення договірних відносин. Безумовно, за цих обставин вимога про віндикацію не може бути застосована: дійсний договір спричинив виникнення права власності у покупця. Відтак, потерпілий може захистити свої законні інтереси шляхом пред'явлення кондикційного позову.

Отже, предметом кондикційного позову може бути індивідуально визначене майно або майно $з$ числа однорідних речей. діï.

Відмінність між віндикацією та кондикцією полягає й у тому, що остання має більш широкий спектр

Як убачається з приписів ст. 1212 ЦК України, положення про кондикцію застосовуються незалежно від того, чи безпідставне набуття або збереження майна було результатом поведінки набувача майна, потерпілого, інших осіб чи наслідком події. Отже, підставами виникнення кондикційних зобов'язань є: дії та події; безвідносно до того чи такі дії є правомірними чи неправомірними, заздалегідь спланованими чи випадковими; йдеться про дії як сторін зобов'язання, так і третіх осіб. Крім того, як слушно наголошується фахівцями, у цьому зобов'язанні не має правового значення чи вибуло майно з володіння власника за його волею або всупереч його волі 9 .

При віндикації, як і при кондикції, майно витребовується із чужого незаконного володіння. Однак, якщо віндикація вичерпується тільки поверненням майна, яке фактично отримав набувач (добросовісний чи недобросовісний), кондикція застосовується для витребування будь-якого збагачення: набутого або збереженого; незалежно від того, у чому воно виражено: майні (речах) чи грошових коштах.

Розглядувані інститути необхідно розрізняти й за способом вибуття майна. За зобов'язанням з безпідставного набуття збереження майна потерпілому повертається майно незалежно від того, яким чином воно вибуло з його володіння (ч. 2 ст. 1212 ЦК України). Тобто кондикційне правовідношення реалізуються незалежно від добросовісності набувача (боржника) та незалежно від того, яким чином майно вибуло $з$ його володіння.

Натомість при віндикації юридичне значення має добросовісність набувача, а також обставини вибуття майна. Так, власник має право витребувати своє майно від недобросовісного набувача у всіх випадках, а в добросовісного набувача - лише тоді, коли воно вибуло з володіння поза його волею (ст. 388 ЦК України). Якщо ж набувач є добросовісним та майно вибуло з володіння первісного власника 3 його волі, віндикація не допускається.

Отже, у віндикації та кондикції добросовісність особи, яка набула (зберегла) у себе майно, розглядається в різних площинах. Від неї в цілому залежить можливість віндикації майна у третьої особи. Водночас щодо кондикційних зобов'язань законодавець не встановлює спеціальних правил про добросовісність чи недобросовісність набувача.

М.М. Кулик, співвідносячи інститут кондикції та віндикації, звертає увагу на такі відмінності: «для задоволення віндикаційного позову необхідно, щоб витребовувана річ була придбана особою, від якої вона витребовується. Кондикційна вимога може бути пред’явлена до набувача не тільки при придбанні, але й при збереженні майна за рахунок іншої особи (потерпілого)»10. Зберегти можна лише своє майно, тобто те, яке належить на підставі титулу, а у випадку віндикації у відповідача перебуває чуже майно. Варто зазначити, що ця підстава не є прийнятною для розмежування кондикції та віндикації в разі наявності добросовісного оплатного набуття майна, оскільки у ст. 388 ЦК України вказується на можливість вибуття майна 3 володіння власника або особи, якій він передав майно у володіння, «іншим шляхом».

Інколи розмежування проводять за критерієм оплатності: для віндикації не завжди важливим $\epsilon$, мало місце зустрічне надання чи ні, тоді як оплатність нівелює безпідставне збагачення11. 3 цим судженням можна погодитися, але тільки із застереженням, що наявність будь-яких договірних відносин усуває можливість застосування норм про кондикцію.

Розмежування між кондикцією та віндикацією фахівці проводять також і за юридичною технікою, яка використовується для їх оформлення. Так, О.А. Шамшов наголошує, що поняття безпідставності майнового 
переміщення при чужому незаконному володінні знаходить своє вираження через більш точні та конкретні поняття, що характеризують право власності, його порушення та захист. У випадку унормування кондикційних відносин яких-небуть техніко-юридичних засобів, які б конкретизували чи уточнювали поняття безпідставності, не визначено ${ }^{12}$. Проте ця особливість, як слушно підкреслює I.М. Гончаров, не стільки визначає різницю між зазначеними інститутами, скільки уточнює сферу застосування віндикації в рамках загального питання безпідставного переміщення майнового блага від однієї особи до іншої13.

3 проведеного аналізу розмежувальних критеріїв можемо дійти висновку, що кондикція є універсальним самостійним способом захисту суб'єктивного цивільного права та дієвим засобом впливу на незаконного набувача. Однак норми, що регулюють кондикційні зобов'язання, можуть субсидіарно застосовуватися до відносин віндикації. Це положення знайшло закріплення у приписах ч. 3 ст. 1212 ЦК України, якою регламентовано, що положення про повернення безпідставно набутого чи збереженого майна застосовуються до вимог про витребування майна власником з чужого незаконного володіння. Такий законодавчий підхід розширює сферу застосування інституту кондикції та покликаний найбільш повно захистити порушені права та законні інтереси учасників цивільного обороту.

Як вбачається з матеріалів судової практики, кондикція застосовується додатково до віндикації, коли певна вимога титульного володільця майна не охоплюється нормативним регулюванням основного способу захисту права ${ }^{14}$. У римському приватному праві утвердилася позиція, що кондикційний позов подається лише у випадку, якщо у зв'язку з втратою права власності відсутня можливість пред’явити віндикаційний позов 15 .

Тобто кондикційний позов застосовується до вимоги про витребування майна з чужого незаконного володіння лише у тому випадку, якщо не достатньо підстав для пред’явлення віндикаційного позову. Такими випадками, до прикладу, є: втрата або інше вибуття майна з незаконного володіння особи; переробка, знищення або пошкодження спірного майна, що спричинило втрату ним індивідуалізуючих ознак або зменшення їх споживчої вартості.

Прикметно, що закріплення на законодавчому рівні норми про додаткове застосування положень про кондикції до віндикаційних вимог вирішило доктринальну полеміку щодо конкуренції цих інститутів. Так, В.В. Ровний, досліджуючи проблему конкуренції позовів, зазначає, що кондикційний позов ніколи не конкурує з віндикаційним, оскільки можливі об'єкти позовних вимог тут взаємовиключають один одного ${ }^{16}$. На наше переконання, ця позиція є цілком обгрунтованою.

Підсумовуючи дослідження питання про співвідношення кондикції та віндикації, можна дійти наступних висновків:

- кондикція є універсальним самостійним способом захисту суб'єктивного цивільного права та дієвим засобом впливу на незаконного набувача;

- норми, що регулюють кондикційні зобов'язання, можуть субсидіарно застосовуватися до відносин про витребування майна з чужого незаконного володіння лише в тому випадку, якщо не достатньо підстав для пред’явлення віндикаційного позову;

- кондикція володіє більш широким спектром дії, ніж віндикація;

- на відміну від віндикації, кондикція може застосовуватися для повернення як родової, так і індивідуально визначеної речі;

- кондикційний позов може бути пред’явлений особою, яка втратила право власності, до власника безпідставно набутого чи збереженого, а також власником втраченого майна до незаконного володільця майна; - конкуренція між кондикційним та віндикаційним позов не допускається. 88149746

1 Постанова Верховного Суду від 05.03.2020 р. у справі № 910/9665/17. URL: http://www.reyestr.court.gov.ua/Review/

2 Постанова Верховного Суду від 01.04.2020 p. у справі № 372/6055/14-ц. URL: https://zakononline.com.ua/courtdecisions/show $/ 88570690$

3 Григорьева М.А. К вопросу о теории охранительных гражданских правоотношений. Вестник КрасГАУ. 2010 . № 6. C. $170-174.173 \mathrm{c}$

4 Постанова Верховного Суду України від 24.09.2014 р. у справі № 6-122 цс14. URL: https://oda.court.gov.ua/sud1590/ pravovipoziciivsu/6-122cs14

5 Флейшиц Е.А. Обязательства из причинения вреда и из неосновательного обогащения. Москва: Госюриздат, 1951. 239 c. 231 c.

6 Постанова Верховного Суду від 18.05.2020 р. у справі № 381/3165/17. URL: http://www.reyestr.court.gov.ua/Review/ 89578914

7 Ківалова Т.С. Особливості зобов'язань, що виникають з набуття, збереження майна без достатньої правової підстави. Актуальні проблеми держави і права. 2010. Вип. 56. С. 218-224. С. 221.

${ }_{8}^{8}$ Мозолин В.П. Гражданское право: учебник. М.: Юристъ, 2007. Ч. 2. С. 876 с.; Былков В.В. Проблемы правоотношений, возникающих вследствие неосновательного обогащения : автореф. дис. ... канд. юрид. наук: 12.00.03. Краснодар, 2004. 28 с. $23 \mathrm{c}$.

9 Романюк Я.М., Майстренко Л.О. Реституція, віндикація, кондикція, відшкодування шкоди: окремі аспекти співвідношення та розмежування. Вісник Верховного Суду України. 2014. № 10. С. 22-31. С. 24; Чепис О.І. Правова природа зобов’язань, що виникають із безпідставного збагачення. Науковий вісник Ужгородського національного університету. 2016. Вип. 41(1). С. 144-147. С. 147 (Серія «Право»).

10 Кулик М.М. Кондикційний позов як юрисдикційний спосіб захисту суб'єктивних цивільних прав інвесторів на бездокументарні цінні папери. Актуальні проблеми приватного права : матеріали наук.-практ. конф., присвяч. 94-й річниці 3 дня народж. В.П. Маслова (19 лют. 2016 р.). Харків, 2016. С. 292-294. С. 293. 
11 Толстой В.С. Проблемы соотношения отдельных исков с иском из неосновательного обогащения. Право Беларуси. 2004. № 13 (85). C. 75-80. 77 C.

12 Шамшов А.А. Обязательства из неосновательного приобретения или сбережения имущества: учеб. пособ. Саратов: Изд-во Сарат. ун-та, 1975. 51 с. 15 с.

13 Гончаров I.М. Співвідношення правових інститутів кондикції та віндикації у цивільному праві. Науковий вісник Ужгородського національного університету. 2015. Вип. 33(1). С. 112-116. С. 113 (Серія «Право»).

14 Постанова Верховного Суду України від 02.03.2016 р. справі № 6-3090цс15. URL: http://www.reyestr.court.gov.ua/ Review/56280404

15 Ваштарева Є.А. Кондикція і віндикація у римському праві. Проблеми законності. 2017. Вип. 139. С. 95-104

16 Ровный В.В. Проблема «конкуренции исков» в современном гражданском праве. Государство и право. 2003 . № 3. C. $96-100$. C. 97.

\section{Резюме}

\section{Романська І.В. До питання про співвідношення кондикції та віндикації.}

Наукову статтю присвячено вирішенню науково-прикладної проблеми розмежування зобов'язання з набуття, збереження майна без достатньої правової підстави з віндикацією. Розглядаються ключові критерії співвідношення позову про витребування майна з чужого незаконного володіння і кондикційного позову.

Установлено, що кондикційне зобов'язання є універсальним самостійним способом захисту суб'єктивного цивільного права. Кондикція застосовується субсидіарно до віндикації, коли певна вимога титульного володільця майна не охоплюється нормативним регулюванням основного способу захисту. Автор доходить висновку про неможливість конкуренції віндикаційного та кондикційного позовів.

Ключові слова: кондикція, віндикація, безпідставне збагачення, критерії співвідношення, конкуренція позовів.

\section{Резюме}

\section{Романская И.В. К вопросу о соотношении кондикции и виндикации.}

Научная статья посвящена решению научно-прикладной проблемы разграничения обязательства по приобретению, сохранению имущества без достаточного правового основания с виндикацией. Рассматриваются ключевые критерии соотношения иска об истребовании имущества из чужого незаконного владения и кондикционного иска.

Установлено, что кондикционное обязательство является универсальным самостоятельным способом защиты субъективного гражданского права. Кондикция применяется субсидиарно к виндикации, когда требование титульного владельца имущества не охватывается нормативным регулированием основного способа защиты. Автор приходит к выводу о невозможности конкуренции виндикационного и кондикционный исков.

Ключевые слова: кондикция, виндикация, неосновательное обогащение, критерии соотношения, конкуренция исков.

\section{Summary}

Iryna Romanska. On the question of the ratio between the condictio and the vindicatio.

The scientific article is devoted to the solution of the scientific-applied problem of delimitation of the obtaining, keeping of property without sufficient legal basis with the vindicatio.

The criteria for the ratio of a reclaim owner's property from someone else's illegal possession and a condictio claim are considered. Both common and distinctive features of these legal institutions are analyzed. Vindicatio and condictio lawsuits are effective ways to protect property rights, not measures of liability.

Obligations arising from the obtaining, keeping of property without sufficient legal basis, as well as reclaim owners property from someone else's illegal possession, by their legal nature belong to the number of renewable, protective and non-contractual legal relations. The similarity can be seen in the so-called criteria as «right to follow». It is concluded that the range of persons entitled to file a condictio claim is wider than the subjects entitled to vindicatio.

The main difference between condictio and vindicatio is that a claim for the return of property from someone else owns without sufficient legal basis is a legal remedy, and a claim for recovery of property from someone else's illegal possession is a legal claim. It is established that in contrast to vindicatio, the fact that the illegal purchaser actually owns the thing, in the case of condictio is not decisive.

It is justified that in comparison with the vindicatio the condictio obligation has a wider range of action and is applied regardless of the good faith of the purchaser and regardless of how the property was taken out of the possession of the creditor.

Based on the generalization of theoretical research, analysis of current legislation of Ukraine, it is established that the obligation of condictio is a universal independent way to protect subjective civil law and an effective means of influencing the illegal acquirer. Condictio is applied in the alternative to vindicatio, when a certain requirement of the titular owner of the property is not covered by the regulations of the main method of protection. The author concludes that it is impossible to compete in vindicatio and condictio claims.

Key words: the condictio, the vindicatio, unjust enrichment, ratio criteria, competition of claims. 